\title{
ANALISIS MINAT BELAJAR PADA PEMBELAJARAN MATEMATIKA
}

\author{
Rizki Nurhana Friantini ${ }^{1)}$, Rahmat Winata ${ }^{2)}$ \\ 1) STKIP Pamane Talino, Ngabang, Indonesia \\ E-mail: rizkinurhanafriantini90@yahoo.co.id \\ 2) STKIP Pamane Talino, Ngabang, Indonesia \\ E-mail:nata_win89@yahoo.com
}

\begin{abstract}
Abstrak. Penelitian ini bertujuan untuk menganalisis dan mendeskrispsikan minat belajar siswa kelas X IIS SMA Negeri 1 Jelimpo tahun ajaran 2018/2019 di Kabupaten Landak. Jenis penelitian ini adalah penelitian kualitatif. Subjek penelitian ini adalah siswa kelas X IIS yang terdiri dari dua kelas yang berjumlah 76 siswa yang ditentukan dengan metode sampling jenuh. Teknik pengumpulan data menggunakan angket. Hasil penelitian menunjukkan bahwa persentase rata-rata jawaban secara keseluruhan adalah 58\%. Dapat disimpulkan bahwa sebagian besar siswa kelas X IIS mempunyai minat belajar pada pembelajaran matematika.. Bila berdasarkan gender, siswa kelas X IIS SMA Negeri 1 Jelimpo berjenis kelamin laki-laki memperoleh persentase rata-rata jawaban secara keseluruhan sebesar 55\% dan siswa berjenis kelamin perempuan memperoleh persentase rata-rata jawaban secara keseluruhan sebesar 62\%. Dapat disimpulkan bahwa sebagian besar siswa laki-laki dan perempuan mempunyai minat belajar pada pembelajaran matematika. Bila dibandingkan antara persentase ratarata minat belajar siswa perempuan lebih besar daripada siswa laki-laki $(62 \%>55 \%)$ sehingga dapat disimpulkan bahwa minat belajar siswa perempuan lebih baik daripada minat belajar siswa laki-laki pada pembelajaran matematika di kelas $\mathrm{X}$ IIS SMA Negeri 1 Jelimpo.
\end{abstract}

Kata kunci: minat belajar; gender; pembelajaran matematika

\section{PENDAHULUAN}

Kualitas pendidikan di Indonesia tergolong masih rendah. Indonesia merupakan negara kepulauan sehingga menyulitkan dalam pemerataan pembangunan. Pembangunan yang belum merata membuat kualitas pendidikan di masingmasing daerah di Indonesia berbeda. Daerah yang maju dan terletak di dekat pusat kota memiliki kualitas pendidikan yang lebih baik sedangkan daerah di pinggir, pedalaman atau perbatasan biasanya mempunyai kualitas pendidikan yang masih rendah.

Dari pengamatan diperoleh hasil bahwa masih banyak daerah yang kurang dalam segi kualitas pendidikan. Misalnya bila dilihat dari kompetensi guru, masih banyak ditemukan guru yang mengajar tidak sesuai dengan bidangnya. Guru matematika di sekolah banyak yang bukan dari jurusan pendidikan matematika. Bila dilihat dari sarana dan prasarana juga banyak ditemukan sekolah yang masih kekurangan, khususnya sekolah-sekolah di daerah-daerah atau di perbatasan. Bila dilihat dari segi siswa, banyak siswa yang lebih mementingkan mencari uang dengan cara menoreh atau bekerja di kebun sawit daripada berangkat sekolah sehingga siswa kerap membolos.

Masih banyaknya permasalahan pada pembelajaran tentunya membuat minat siswa untuk belajar menjadi rendah. Padahal Sukada dkk (2013:5) berpendapat bahwa minat merupakan aspek kepribadian yang berkaitan dengan prestasi belajar. Sejalan dengan pendapat tersebut, Komariyah dkk (2018:3) menyebutkan kenyataan bahwa prestasi siswa akan lebih baik apabila memiliki minat yang besar terhadap pelajaran yang diajarkan. Jika pendidikan menghadapi persoalan rendahnya minat belajar siswa maka kondisi ini akan menghambat tercapainya tujuan belajar yaitu untuk mencapai perubahan kognitif, afektif dan psikomotor pada dirinya. Oleh karena minat berkaitan dengan prestasi belajar sebaiknya guru lebih memberikan perhatian kepada minat belajar siswa.

Minat menurut Slameto (2010:180) adalah suatu rasa lebih suka dan rasa keterikatan pada suatu hal atau aktivitas, tanpa ada yang menyuruh. Sejalan dengan itu, minat berarti kecenderungan dan kegairahan yang tinggi atau keinginan 


\section{- - - Jurnal Pendidikan Matematika Indonesia \\ Volum 4 Nomor 1 bulan Maret 2019 Page 6 - 11 \\ p-ISSN: 2477-5967 e-ISSN: 2477-8443}

yang besar terhadap sesuatu (Syah 2003, Siagian, 2015:126). Menurut Nisa dkk (2017:59) minat merupakan alat motivasi yang utama yang dapat membangkitkan kegairahan belajar siswa dalam rentangan waktu tertentu. Minat menunjuk kepada kesukaan atau kesenangan yang diperoleh dari aktivitas diri (Woolfolk 1993, Sukada dkk, 2013:6).

Sedangkan minat belajar menurut Guilford (Lestari dan Mokhammad, 2017:93) adalah dorongan-dorongan dari dalam diri siswa secara psikis dalam mempelajari sesuatu dengan penuh kesadaran, ketenangan, dan kedisiplinan sehingga menyebabkan individu secara aktif dan senang untuk melakukannya. Menurut Hidayat dan Djamilah (2018:66) minat belajar siswa dapat diartikan sebagai suatu keadaan siswa yang dapat menumbuhkan rasa suka dan dapat membangkitkan semangat diri dalam melakukan suatu kegiatan yang dapat diukur melalui rasa suka, tertarik, memiliki perhatian dan keterlibatan dalam mengikuti proses pembelajaran. Kemudian Sari dan Esti (2015:62) menyatakan minat belajar siswa merupakan rasa ketertarikan siswa terhadap belajar di mana siswa tersebut ingin mendalami, maupun melakukan sehingga terjadi perubahan pada diri siswa tersebut.

Minat belajar merupakan sifat yang penting untuk dimiliki oleh siswa. Hurlock (dalam Sukada dkk, 2013:6) mengatakan bahwa 1) minat mempengaruhi bentuk dan itensitas cita-cita, misalnya orang yang menaruh minat matematika akan bercita-cita menjadi ahli matematika, yang hebat, atau menjadi orang yang ahli dalam bidang matematika, 2) minat dapat berfungsi sebagai pendorong yang kuat, siswa yang berminat pada matematika akan terdorong untuk melakukan kegiatan yang berhubungan dengan matematika, 3) prestasi selalu dipengaruhi oleh jenis dan intensitas minat seseorang, siswa yang berminat pada matematika akan berusaha mendapat nilai yang bagus dalam matematika, 4) minat menimbulkan kepuasan, siswa cenderung mengulang kegiatan yang berhubungan dengan minatnya.

Minat belajar tidak tumbuh dengan sendirinya apalagi ada sejak lahir. Menurut Djaali (2014:122) minat adalah kecenderungan hati yang tinggi terhadap sesuatu. Minat tidak timbul sendirian, ada unsur kebutuhan. Sedangkan menurut Slameto (2010:180) bila siswa menyadari bahwa belajar merupakan suatu alat untuk mencapai beberapa tujuan yang dianggapnya penting, dan bila siswa melihat bahwa hasil dari pengalaman belajarnya akan membawa kemajuan pada dirinya, kemungkinan besar ia akan berminat untuk mempelajarinya. Dari pendapat tersebut dapat disimpulkan bahwa agar siswa mempunyai minat belajar maka berilah kesadaran kepada siswa bahwa dengan belajar membawa kemajuan untuk dirinya. Kemudian menurut Singers (dalam Darmadi, 2017:317) faktor-faktor yang mempengaruhi timbulnya minat belajar adalah 1) pelajaran akan menarik siswa jika terlihat adanya hubungan antara pelajaran dan kehidupan nyata, 2) bantuan yang diberikan guru terhadap anak didiknya dalam mencapai tujuan tertentu, 3) adanya kesempatan yang diberikan guru terhadap siswa untuk berperan aktif dalam proses belajar mengajar, 4) sikap yang diperlihatkan guru dalam usaha meningkatkan minat siswa, sikap seorang guru yang tidak disukai oleh anak didik tertentu akan mengurangi minat dan perhatian siswa terhadap mata pelajaran yang diajarkan oleh guru yang bersangkutan.

Selanjutnya menurut Lestari dan Mokhammad (2017:9394), indikator dari minat belajar adalah 1) perasaan senang, 2) ketertarikan untuk belajar, 3) menunjukkan perhatian saat belajar, 4) keterlibatan dalam belajar. Sedangkan indiktor minat belajar menurut Darmadi (2017:322) adalah 1) adanya pemusatan perhatian, perasaan dan pikiran dari subjek terhadap pembelajaran karena adanya ketertarikan, 2) adanya perasaan senang terhadap pembelajaran, 3) adanya kemauan dan kecenderungan pada diri subjek untuk terlihat aktif dalam pembelajaran serta untuk mendapat hasil yang terbaik baik. Dari beberapa indikator tersebut dapat disimpulkan bahwa indikator minat belajar adalah 1) adanya perasaan senang terhadap pembelajaran, 2) adanya pemusatan perhatian dan pikiran terhadap pembelajaran, 3) adanya kemauan untuk belajar, 4) adanya kemauan dari dalam diri untuk aktif dalam pembelajaran, 5) adanya upaya yang dilakukan untuk merealisasikan keinginan untuk belajar.

Oleh karena itu akan dilakukan analisis untuk melihat bagaimana minat belajar siswa pada saat pembelajaran matematika di kelas X IIS SMA Negeri 1 Jelimpo secara klasikal dan berdasarkan gender. Diharapkan dengan menganalisis minat belajar siswa dapat diketahui sejauh mana tingkat minat belajar yang dimiliki siswa baik secara klasikal maupun berdasarkan gender khususnya pada pembelajaran matematika sehingga dapat menjadi evaluasi dan diperoleh solusi untuk lebih meningkatkan lagi minat belajar siswa.

\section{METODE PENELITIAN}

Jenis penelitian ini merupakan penelitian kualitatif deskriptif. Teknik pengambilan sampel adalah sampling jenuh. Menurut Sugiyono (2010:124) sampling jenuh adalah teknik penentuan sampel bila semua anggota populasi digunakan sebagai sampel. Oleh karena itu, subjek pada penelitian ini adalah siswa kelas X IIS di SMA Negeri 1 Jelimpo pada tahun ajaran 2018/2019. Kelas X IIS terdiri dari dua kelas yaitu kelas X IIS A yang berjumlah 38 siswa dan X IIS B yang berjumlah 38 siswa sehingga total keseluruhan adalah 76 siswa. dengan jumlah siswa laki-laki sebesar 43 siswa dan siswa perempuan sebesar 33 siswa. Pada penelitian ini metode yang digunakan untuk pengambilan data adalah metode non tes yang berupa kuisioner/angket. Menurut Sugiyono (2010:199) kuisioner/angket merupakan teknik pengumpulan data yang dilakukan dengan cara memberi seperangkat pertanyaan atau pernyataan tertulis kepada responden untuk dijawabnya. Angket yang digunakan terdiri dari 30 pertanyaan yang disesuaikan dengan indikator minat belajar untuk memperoleh data mengenai minat belajar siswa pada pembelajaran matematika.

Analisis data yang digunakan dalam penelitian ini adalah: Untuk menghitung persentase rata-rata jawaban siswa per item pernyataan ditentukan dengan rumus:

$$
\overline{\mathrm{P}}_{1}=\frac{\sum \mathrm{f}_{\mathrm{i}} \mathrm{P}_{\mathrm{i}}}{\mathrm{n}} \times 100 \%
$$




\section{OJPMI}

Jurnal Pendidikan Matematika Indonesia

Volum 4 Nomor 1 bulan Maret 2019 Page 6 - 11

p-ISSN: 2477-5967 e-ISSN: 2477-8443
Keterangan:

$\bar{P}_{\iota}=$ persentase rata-rata jawaban siswa untuk item pernyataan ke-i

$f_{i}=$ frekuensi pilihan jawaban siswa untuk item pernyataan ke-i

$P_{i}=$ persentase pilihan jawaban siswa untuk item pernyataan ke-i

$\mathrm{n}$ = banyaknya siswa

Untuk menghitung persentase rata-rata jawaban siswa per indikator dan secara keseluruhan ditentukan dengan rumus:

Keterangan :

$$
\overline{\mathrm{P}_{\mathrm{T}}}=\frac{\sum \overline{\mathrm{P}_{1}}}{\mathrm{k}} \times 100 \%
$$

$\overline{P_{T}}=$ persentase rata-rata jawaban siswa per indikator atau secara keseluruhan

$\bar{P}_{\iota}=$ persentase rata-rata jawaban siswa untuk item

pernyataan ke-i

$\mathrm{k}$ = banyaknya item pernyataan

TABEL I

Kriteria PENAFsiran PERSENTASE JAWABAN ANGKet

\begin{tabular}{cc}
\hline Kriteria & Penafsiran \\
\hline $\mathrm{P}=0 \%$ & Tak seorang pun \\
$0 \%<\mathrm{P}<25 \%$ & Sebagian kecil \\
$25 \% \leq \mathrm{P} \leq 50 \%$ & Hampir setengahnya \\
$\mathrm{P}=50 \%$ & Setengahnya \\
$50 \%<\mathrm{P}<75 \%$ & Sebagian besar \\
$75 \% \leq \mathrm{P} \leq 100 \%$ & Hampir seluruhnya \\
$\mathrm{P}=100 \%$ & Seluruhnya \\
\hline \multicolumn{2}{r}{ Lestari dan Mokhammad $(2017: 335-337)$}
\end{tabular}

\section{HASIL DAN PEMBAHASAN}

Hasil dari pengolahan data penelitian mengenai minat belajar pada pembelajaran matematika siswa kelas X IIS SMA Negeri 1 Jelimpo. Setelah diperoleh data dari hasil angket, selanjutnya data tersebut diolah dalam bentuk tabel deskriptif persentase.

1. Secara klasikal

Secara klasikal, dari data angket yang terdiri dari 30 butir pernyataan yang diberikan kepada siswa kelas $\mathrm{X}$ IIS SMA Negeri 1 Jelimpo yang terdiri dari 76 siswa diperoleh persentase rata-rata jawaban secara keseluruhan sebesar 58\% dapat disimpulkan bahwa sebagian besar siswa mempunyai minat belajar pada pembelajaran matematika. Tetapi persentase yang diperoleh masih termasuk rendah sehingga dapat disimpulkan bahwa minat belajar siswa kelas X IIS SMA Negeri 1 Jelimpo pada pembelajaran matematika masih rendah.

Untuk melihat hasil persentase minat belajar berdasarkan indikator dapat dilakukan dengan menganalisis jawaban siswa untuk masing-masing indikator minat belajar. Minat belajar pada pembelajaran matematika diukur dengan menggunakan angket berdasarkan 5 indikator. Hasil analisis persentase per masing-masing indikator dapat dilihat pada Tabel II.
TABEL II

Hasil PERSENTASE INDIKATOR MinAt BELAJAR Siswa

\begin{tabular}{clcc}
\hline No & \multicolumn{1}{c}{ Indikator } & $\begin{array}{c}\text { Persentase } \\
\text { rata-rata }\end{array}$ & Penafsiran \\
\hline 1 & $\begin{array}{l}\text { Adanya perasaan } \\
\text { senang terhadap } \\
\text { pembelajaran } \\
\text { Adanya pemusatan } \\
\text { perhatian dan pikiran } \\
\text { terhadap } \\
\text { pembelajaran }\end{array}$ & $54 \%$ & Sebagian besar \\
3 & $\begin{array}{l}\text { Adanya kemauan } \\
\text { untuk belajar }\end{array}$ & Sebagian besar \\
4 & $\begin{array}{l}\text { Adanya kemauan dari } \\
\text { dalam diri untuk aktif } \\
\text { belajar } \\
\text { Adanya upaya yang } \\
\text { dilakukan untuk } \\
\text { merealisasikan } \\
\text { keinginan untuk } \\
\text { belajar }\end{array}$ & $61 \%$ & Setengahnya \\
\hline Berdasarkan jawaban besar \\
\hline
\end{tabular}

Berdasarkan jawaban siswa pada indikator pertama yaitu adanya perasaan senang terhadap pembelajaran diperoleh persentase rata-rata $54 \%$ dapat disimpulkan bahwa sebagian besar siswa merasakan senang dengan pembelajaran matematika. Untuk indikator kedua yaitu adanya pemusatan perhatian dan pikiran terhadap pembelajaran diperoleh rata-rata $67 \%$. Dapat disimpulkan bahwa sebagian besar siswa dapat memusatkan perhatian dan pikiran terhadap pembelajaran. Untuk indikator ketiga yaitu adanya kemauan untuk belajar diperoleh rata-rata 50\%. Dapat disimpulkan bahwa setengahnya dari keseluruhan siswa mempunyai keinginan untuk belajar. Untuk indikator keempat yaitu adanya kemauan dari dalam diri untuk aktif belajar diperoleh persentase rata-rata $61 \%$. Dapat disimpulkan bahwa sebagian besar siswa mempunyai kemauan untuk aktif belajar selama pembelajaran matematika. Untuk indikator yang terakhir yaitu adanya upaya yang dilakukan dari dalam diri untuk merealisasikan keinginan untuk belajar diperoleh ratarata 55\%. Dapat disimpulkan bahwa sebagian besar siswa mempunyai upaya yang dilakukannya untuk merealisasikan keinginan untuk belajar.

Dari hasil di atas dapat dilihat bahwa hasil persentase dari masing-masing indikator masih termasuk rendah. Dari lima indikator yang paling rendah persentasenya adalah indikator ketiga yaitu adanya kemauan untuk belajar dapat disimpulkan bahwa siswa belum mempunyai kemauan yang besar untuk belajar. Tetapi siswa masih mau berusaha untuk berpikir dan memperhatikan selama pembelajaran, terlihat dari persentase yang tertinggi ada pada indikator kedua yaitu adanya pemusatan perhatian dan pikiran untuk belajar. Secara keseluruhan bila dilihat dari masing-masing indikator dapat disimpulkan bahwa hanya setengah dari siswa yang mau untuk belajar, siswa masih kurang senang dalam pembelajaran, siswa belum mau untuk aktif dan berupaya dalam pembelajaran. 
2. Berdasarkan gender

Bila berdasarkan gender, dari data angket yang diberikan kepada siswa kelas X IIS SMA Negeri 1 Jelimpo berjenis kelamin laki-laki yang terdiri dari 43 siswa diperoleh persentase rata-rata jawaban secara keseluruhan sebesar $55 \%$ dapat disimpulkan bahwa sebagian besar siswa laki-laki mempunyai minat belajar pada pembelajaran matematika. Tetapi persentase yang diperoleh masih termasuk rendah sehingga dapat disimpulkan bahwa minat belajar siswa kelas X IIS SMA Negeri 1 Jelimpo yang berjenis kelamin laki-laki pada pembelajaran matematika rendah.

Untuk siswa berjenis kelamin perempuan yang terdiri dari 33 siswa diperoleh persentase rata-rata jawaban secara keseluruhan sebesar 62\%. Dapat disimpulkan bahwa sebagian besar siswa perempuan mempunyai minat belajar pada pembelajaran matematika. Tetapi persentase yang diperoleh juga termasuk rendah sehingga dapat disimpulkan bahwa minat belajar siswa kelas X IIS SMA Negeri 1 Jelimpo yang berjenis kelamin perempuan pada pembelajaran matematika rendah. Bila dibandingkan antara persentase rata-rata minat belajar siswa perempuan lebih besar daripada siswa laki-laki $(62 \%>55 \%)$ sehingga dapat disimpulkan bahwa minat belajar siswa perempuan sedikit lebih baik daripada minat belajar siswa laki-laki pada pembelajaran matematika di kelas X IIS SMA Negeri 1 Jelimpo.

Sedangkan untuk persentase rata-rata jawaban siswa laki-laki per masing-masing indikator dapat dilihat pada Tabel III.

TABEL III

HASIL PERSENTASE INDIKATOR MINAT BELAJAR SiSWA LAKI-LAKI

\begin{tabular}{clcc}
\hline No & \multicolumn{1}{c}{ Indikator } & $\begin{array}{c}\text { Persentase } \\
\text { rata-rata }\end{array}$ & Penafsiran \\
\hline 1 & $\begin{array}{l}\text { Adanya perasan } \\
\text { senang terhadap } \\
\text { pembelajaran } \\
\text { Adanya pemusatan } \\
\text { perhatian dan pikiran } \\
\text { terhadap pembelajaran }\end{array}$ & $51 \%$ & $\begin{array}{c}\text { Sebagian } \\
\text { besar }\end{array}$ \\
Adanya kemauan untuk \\
belajar
\end{tabular}

perhatian dan pikiran terhadap pembelajaran. Untuk indikator ketiga yaitu adanya kemauan untuk belajar diperoleh rata-rata $48 \%$. Dapat disimpulkan bahwa hampir setengahnya dari keseluruhan siswa laki-laki mempunyai keinginan untuk belajar. Untuk indikator keempat yaitu adanya kemauan dari dalam diri untuk aktif belajar diperoleh persentase rata-rata $60 \%$. Dapat disimpulkan bahwa sebagian besar siswa laki-laki mempunyai kemauan untuk aktif belajar selama pembelajaran matematika. Untuk indikator yang terakhir yaitu adanya upaya yang dilakukan dari dalam diri untuk merealisasikan keinginan untuk belajar diperoleh rata-rata 53\%. Dapat disimpulkan bahwa sebagian besar siswa laki-laki mempunyai upaya yang dilakukannya untuk merealisasikan keinginan untuk belajar.

Dari hasil di atas dapat dilihat bahwa hasil persentase dari masing-masing indikator masih termasuk rendah. Dari lima indikator yang paling rendah persentasenya adalah indikator ketiga yaitu adanya kemauan untuk belajar. Dapat disimpulkan bahwa siswa laki-laki belum mempunyai kemauan yang besar untuk belajar. Sedangkan indikator yang paling tinggi persentasinya adalah indikator kedua yaitu adanya pemusatan perhatian dan pikiran untuk belajar. Secara keseluruhan bila dilihat dari masing-masing indikator dapat disimpulkan bahwa hampir setengah dari total keseluruhan siswa laki-laki yang mau untuk belajar, siswa laki-laki masih kurang senang untuk belajar dan belum berupaya maksimal untuk memperhatikan dan aktif pada saat pembelajaran.

Sedangkan untuk persentase rata-rata jawaban siswa perempuan per masing-masing indikator dapat dilihat pada Tabel IV.

TABEL IV

Hasil Persentase IINDikator Minat Belajar Siswa Perempuan

\begin{tabular}{clcc}
\hline No & \multicolumn{1}{c}{ Indikator } & $\begin{array}{c}\text { Persentase } \\
\text { rata-rata }\end{array}$ & Penafsiran \\
\hline 1 & $\begin{array}{l}\text { Adanya perasaan senang } \\
\text { terhadap pembelajaran }\end{array}$ & $62 \%$ & $\begin{array}{c}\text { Sebagian } \\
\text { besar }\end{array}$ \\
2 & $\begin{array}{l}\text { Adanya pemusatan } \\
\text { perhatian dan pikiran } \\
\text { terhadap pembelajaran } \\
\text { Adanya kemauan untuk } \\
\text { belajar }\end{array}$ & $72 \%$ & $\begin{array}{c}\text { Sebagian } \\
\text { besar }\end{array}$ \\
4 & $\begin{array}{l}\text { Adanya kemauan dari } \\
\text { dalam diri untuk aktif } \\
\text { belajar } \\
\text { Adanya upaya yang } \\
\text { dilakukan untuk } \\
\text { merealisasikan } \\
\text { keinginan untuk belajar }\end{array}$ & $63 \%$ & $\begin{array}{c}\text { Sebagian } \\
\text { besar }\end{array}$ \\
Berdasarkan jawaban siswa perempuan pada \\
besar
\end{tabular}

indikator pertama yaitu adanya perasaan senang terhadap pembelajaran diperoleh persentase rata-rata 62\%. Dapat disimpulkan bahwa sebagian besar siswa perempuan merasakan senang dengan pembelajaran matematika. Untuk indikator kedua yaitu adanya pemusatan perhatian dan pikiran terhadap pembelajaran 


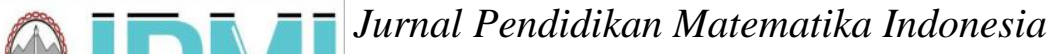 \\ Volum 4 Nomor 1 bulan Maret 2019 Page 6 - 11 \\ p-ISSN: 2477-5967 e-ISSN: 2477-8443}

diperoleh rata-rata $72 \%$. Dapat disimpulkan bahwa sebagian besar siswa perempuan dapat memusatkan perhatian dan pikiran terhadap pembelajaran. Untuk indikator ketiga yaitu adanya kemauan untuk belajar diperoleh rata-rata 55\%. Dapat disimpulkan bahwa sebagian besar dari keseluruhan siswa perempuan mempunyai keinginan untuk belajar. Untuk indikator keempat yaitu adanya kemauan dari dalam diri untuk aktif belajar diperoleh persentase rata-rata 63\%. Dapat disimpulkan bahwa sebagian besar siswa perempuan mempunyai kemauan untuk aktif belajar selama pembelajaran matematika. Untuk indikator yang terakhir yaitu adanya upaya yang dilakukan dari dalam diri untuk merealisasikan keinginan untuk belajar diperoleh rata-rata 59\%. Dapat disimpulkan bahwa sebagian besar siswa perempuan mempunyai upaya yang dilakukannya untuk merealisasikan keinginan untuk belajar.

Dari hasil di atas dapat dilihat bahwa hasil persentase dari masing-masing indikator masih termasuk rendah. Dari lima indikator yang paling rendah persentasenya adalah indikator ketiga yaitu adanya kemauan untuk belajar. Dapat disimpulkan bahwa siswa perempuan belum mempunyai kemauan yang besar untuk belajar. Sedangkan indikator yang paling tinggi persentasinya adalah indikator kedua yaitu adanya pemusatan perhatian dan pikiran untuk belajar. Secara keseluruhan bila dilihat dari masing-masing indikator dapat disimpulkan sebagian besar siswa perempuan mempunyai perasaan senang dan kemauan untuk belajar serta berupaya untuk aktif dan memperhatikan selama pembelajaran matematika.

Untuk perbandingan persentase rata-rata jawaban siswa laki-laki dan perempuan per masing-masing indikator dapat dilihat pada Tabel V.

TABEL V

PERBANDingan Hasil Persentase IINDIKATOR MinAt BelajaR SISWA LAKI-LAKI DAN PEREMPUAN

\begin{tabular}{clcc}
\hline \multirow{2}{*}{ No } & \multicolumn{1}{c}{ Indikator } & \multicolumn{2}{c}{ Persentase rata-rata } \\
& \multicolumn{1}{c}{ Laki-laki } & Perempuan \\
\hline 1 & $\begin{array}{l}\text { Adanya perasaan senang } \\
\text { terhadap pembelajaran } \\
\text { Adanya pemusatan } \\
\text { perhatian dan pikiran } \\
\text { terhadap pembelajaran } \\
3\end{array}$ & $51 \%$ & $62 \%$ \\
Adanya kemauan untuk \\
belajar \\
Adanya kemauan dari \\
dalam diri untuk aktif \\
belajar \\
$\begin{array}{l}\text { Adanya upaya yang } \\
\text { dilakukan untuk } \\
\text { merealisasikan keinginan } \\
\text { untuk belajar }\end{array}$ & $64 \%$ & $72 \%$ \\
\hline
\end{tabular}

Pada indikator pertama yaitu adanya perasaan senang terhadap pembelajaran, siswa laki-laki memperoleh persentase rata-rata $51 \%$ sedangkan siswa perempuan sebesar 62\%. Dapat disimpulkan bahwa sebagian besar siswa perempuan lebih mempunyai perasaan senang terhadap pembelajaran matematika daripada sebagian besar siswa laki-laki. Untuk indikator kedua yaitu adanya pemusatan perhatian dan pikiran terhadap pembelajaran, siswa laki-laki memperoleh rata-rata $64 \%$ sedangkan siswa perempuan sebesar $72 \%$. Dapat disimpulkan bahwa sebagian besar siswa perempuan lebih dapat memusatkan perhatian dan pikiran terhadap pembelajaran matematika daripada sebagian besar siswa laki-laki. Untuk indikator ketiga yaitu adanya kemauan untuk belajar, siswa laki-laki memperoleh rata-rata $48 \%$ sedangkan siswa perempuan sebesar 55\%. Dapat disimpulkan bahwa sebagian besar siswa perempuan lebih mempunyai kemauan untuk belajar daripada hampir setengah dari siswa laki-laki. Untuk indikator keempat yaitu adanya kemauan dari dalam diri untuk aktif belajar, siswa laki-laki memperoleh persentase rata-rata $60 \%$ sedangkan siswa perempuan sebesar 63\%. Dapat disimpulkan bahwa sebagian besar siswa perempuan lebih mempunyai kemauan untuk aktif belajar selama pembelajaran matematika daripada sebagian besar siswa laki-laki. Untuk indikator yang terakhir yaitu adanya upaya yang dilakukan dari dalam diri untuk merealisasikan keinginan untuk belajar, siswa laki-laki memperoleh rata-rata 53\% sedangkan siswa perempuan sebesar 59\%. Dapat disimpulkan bahwa sebagian besar siswa perempuan lebih mempunyai upaya yang dilakukannya untuk merealisasikan keinginan untuk belajar matematika daripada sebagian besar siswa laki-laki. Secara keseluruhan pada masing-masing indikator minat belajar, siswa perempuan memperoleh persentase yang lebih tinggi daripada siswa laki-laki, sehingga dapat disimpulkan bahwa minat belajar pada pembelajaran matematika untuk siswa perempuan lebih baik daripada siswa laki-laki pada kelas X IIS SMA Negeri 1 Jelimpo. Hasil ini dimungkinkan karena menurut penelitian Amir (2013:28) siswa perempuan lebih unggul dalam kemampuan komunikasi matematis, lebih termotivasi, terorganisasi dalam belajar. Oleh karena itu siswa perempuan mempunyai minat belajar matematika yang lebih baik daripada siswa laki-laki. Hasil ini berlawanan dengan penelitian Rojabiyah dan Wahyu (2018:463) yang memperoleh hasil minat belajar siswa laki-laki terhadap pembelajaran matematik lebih baik dibandingkan siswa perempuan.

\section{KESIMPULAN DAN SARAN}

Secara klasikal, dari data angket yang diberikan kepada siswa kelas X IIS SMA Negeri 1 Jelimpo diperoleh persentase rata-rata jawaban secara keseluruhan sebesar 58\% dapat disimpulkan bahwa sebagian besar siswa kelas $\mathrm{X}$ IIS mempunyai minat belajar pada pembelajaran matematika. Bila dilihat dari masing-masing indikator dapat disimpulkan bahwa hanya setengah dari siswa yang mau untuk belajar, dan sebagian besar siswa senang dalam pembelajaran, sebagian besar siswa memusatkan perhatian pada pembelajaran, dan 
sebagian besar siswa mau untuk aktif dan berupaya dalam pembelajaran.

Bila berdasarkan gender, dari data angket yang diberikan kepada siswa kelas X IIS SMA Negeri 1 Jelimpo berjenis kelamin laki-laki diperoleh persentase rata-rata jawaban secara keseluruhan sebesar 55\% dapat disimpulkan bahwa sebagian besar siswa laki-laki mempunyai minat belajar pada pembelajaran matematika. Untuk siswa berjenis kelamin perempuan diperoleh persentase rata-rata jawaban secara keseluruhan sebesar 62\%. Dapat disimpulkan bahwa sebagian besar siswa perempuan mempunyai minat belajar pada pembelajaran matematika. Bila dibandingkan antara persentase rata-rata minat belajar siswa perempuan lebih besar daripada siswa laki-laki $(62 \%>55 \%)$ sehingga dapat disimpulkan bahwa minat belajar siswa perempuan lebih baik daripada minat belajar siswa laki-laki pada pembelajaran matematika di kelas X IIS SMA Negeri 1 Jelimpo. Bila dilihat berdasarkan masing-masing indikator juga memperoleh hasil bahwa persentase rata-rata jawaban siswa perempuan lebih tinggi dari siswa laki-laki di kelas X IIS SMA Negeri 1 Jelimpo. Hal ini menunjukkan bahwa siswa perempuan lebih memiliki perasaan senang pada pembelajaran, lebih dapat memusatkan perhatian pada pembelajaran, dan lebih aktif berupaya dalam pembelajaran dibandingkan dengan siswa laki-laki pada pembelajaran matematika di kelas X IIS SMA Negeri 1 Jelimpo.

Sebaiknya guru lebih memperhatikan minat belajar siswa selama pembelajaran, khususnya pada pembelajaran matematika yang biasanya menjadi mata pelajaran yang tidak disukai siswa sehingga pasti pada pembelajaran matematika siswa kurang berminat dalam belajar. Sebaiknya dalam pembelajaran matematika lebih dihubungkan antara materi dengan kehidupan nyata sehingga dapat membuat siswa lebih berminat untuk belajar. Selain itu sebaiknya guru menggunakan metode pembelajaran yang dapat membuat siswa berminat untuk belajar yaitu metode pembelajaran yang lebih bervariasi atau lebih menyenangkan seperti pembelajaran dengan menggunakan games atau bermain peran dan lainnya sehingga siswa menjadi lebih tertarik untuk belajar matematika dan berminat untuk melaksanakan pembelajaran matematika.

\section{REFERENSI}

Amir, Zubaidah. 2013. Perspektif Gender dalam Pembelajaran Matematika. Marwah. Vol. XII, No. 1, Juni, Tahun 2013.
Darmadi. (2017). Pengembangan Model dan Metode Pembelajaran dalam Dinamika Belajar Siswa. Yogyakarta: Deepublish.

Djaali. (2014). Psikologi Pendidikan. Jakarta. Bumi Aksara. Hidayat, Puput Wahyu dan Djamilah Bondan Widjajanti. (2018). Analisis Kemampuan Berpikir Kreatif dan Minat Belajar Siswa dalam Mengerjakan Soal Open Ended dengan Pendekatan CTL. Pythagoras: Jurnal Pendidikan Matematika. Vol. 13, No. 1, Hal. 63-75.

Komariyah, Siti dkk. (2018). Analisis Pemahaman Konsep dalam Memecahkan Masalah Matematika Ditinjau dari Minat Belajar Siswa. Sosiohumaniora. Vol. 4, No. 1, Februari 2018.

Lestari, Karunia Eka dan Mokhammad Ridwan Yudhanegara. (2017). Peneltian Pendidikan Matematika. Bandung: Refika Aditama.

Nisa dkk. (2017). Penyusunan Skala Minat Belajar Matematika dengan Penerapan Model Rasch. Jurnal Pendidikan MIPA Pancasakti. Vol. 1, No. 1, 2017, Hal. 58-64.

Rojabiyah, Asiah Badriyatur dan Wahyu Setiawan. 2018. Analisis Minat Belajar Siswa MTs Kelas VII dalam Pembelajaran Matematik Materi Aljabar Berdasarkan Gender. Journal on Education. Vol. 01, No. 02, Februari, hal 458-463.

Sari, Fitri Mustika dan Esti Harini. (2015). Hubungan Persepsi Siswa terhadap Mata Pelajaran Matematika Minat Belajar dan Kemandirian Belajar dengan Hasil Belajar Matematika. Union: Jurnal Pendidikan Matematika. Vol. 3, No. 1, Maret 2015.

Siagian, Roida Eva Flora. (2015). Pengaruh Minat dan Kebiasaan Belajar Siswa terhadap Prestasi Belajar Matematika. Jurnal Formatif. Vol. 2, No. 2, Hal. 122131.

Slameto. (2010). Belajar \& Faktor-faktor yang Mempengaruhi. Jakarta: Rineka Cipta.

Sugiyono. (2010). Metode Penelitian Pendidikan. Bandung: Alfabeta.

Sukada dkk. (2013). Kontribusi Minat Belajar, Motivasi Berprestasi dan Kecerdasan Logis Matematika terhadap Hasil Belajar Matematika Siswa SMA Negeri 1 Kintamani. e-Journal Program Pascasarjana Universitas Pendidikan Ganesha. Vol 4, Tahun 2013. 